\title{
Penerapan Strategi Pembelajaran Neighborhood Walk Untuk Meningkatkan Kemampuan Menulis Siswa Kelas XI Perkantoran-1 SMK Negeri 1 Polewali
}

\section{Halimah}

\author{
Guru SMK Negeri 1 Polewali, Sulawesi Barat
}

\begin{abstract}
ABSTRAK
Penelitian ini bertujuan mendeskripsikan peningkatan kemampuan siswa Kelas XI Perkantoran-1 SMK Negeri 1 Polewali dalam menulis melalui strategi pembelajaran Neighborhood Walk.

Penelitian ini merupakan penelitian tindakan kelas yang dilakukan dalam tiga siklus. Subjek penelitian adalah siswa kelas XI Perkantoran-1 SMK Negeri 1 Polewali Semester Ganjil tahun pelajaran 2018/2019, yang berjumlah 31 siswa. Teknik pengumpulan data yang digunakan adalah observasi dan portofolio. Keseluruhan data yang diperoleh dianalisis dengan melalui tahap-tahap: (1) menelaah seluruh data, (2) mereduksi data, (3) menyajikan data, dan (4) menyimpulkan hasil penulisan.

Hasil penelitian menunjukkan bahwa pada siklus pertama karangan deskripsi yang dibuat siswa hanya 19 siswa atau 61,29\% yang mencapai nilai KKM (75), sedangkan 12 siswa atau 38,71\% nilainya masih berada di bawah nilai KKM. Setelah pelaksanaan tindakan pada siklus kedua, hasil penilaian tulisan siswa menunjukkan bahwa hanya 4 siswa atau $12,90 \%$ yang nilainya tidak mencapai nilai KKM, sedangkan 27 siswa atau 87,10\% yang nilainya mencapai bahkan melampaui nilai KKM. Selanjutnya, pada siklus ketiga, 31 siswa dinyatakan tuntas atau $100 \%$. Jadi, penerapan strategi Neighborhood Walk dapat meningkatkan kemampuan menulis siswa kelas XI Perkantoran-1 SMK Negeri 1 Polewali.

Berdasarkan hasil menulis dan simpulan yang telah dikemukakan maka disarankan agar guru bahasa Indonesia menerapkan strategi pembelajaran neighborhood walk dalam meningkatkan kemampuan menulis siswa.
\end{abstract}

Kata Kunci: Neighborhood Walk, Kemampuan Menulis.

\section{PENDAHULUAN}

Mata pelajaran Bahasa Indonesia menjadi modal dasar untuk belajar dan perkembangan anak-anak Indonesia. Mata pelajaran Bahasa Indonesia membina dan mengembangkan kepercayaan diri peserta didik sebagai komunikator, pemikir imajinatif, dan warga negara Indonesia yang literat atau melek informasi. Pembelajaran bahasa Indonesia bertujuan membina dan mengembangkan pengetahuan dan keterampilan berkomunikasi yang dibutuhkan peserta didik dalam menempuh pendidikan dan dunia kerja (Suherli, dkk., 2017).

Sesuai dengan hakikat pembelajaran bahasa Indonesia tersebut, pembelajaran bahasa Indonesia di tingkat sekolah menengah lebih ditekankan pada aspek-aspek penguasaan keterampilan berbahasa. Suparno (2001:1) menyatakan bahwa pembelajaran bahasa Indonesia diarahkan untuk 
membentuk kompetensi komunikatif, yakni kemampuan menggunakan bahasa Indonesia sebagai alat komunikasi, baik aspek pemahaman, aspek penggunaan, maupun aspek apresiasi.

Aktivitas menulis merupakan suatu bentuk manifestasi kemampuan dan keterampilan berbahasa paling akhir dikuasai pelajar bahasa setelah kemampuan mendengarkan, berbicara, dan membaca. Dibandingkan tiga kemampuan berbahasa yang lain, kemampuan menulis lebih sulit dikuasai bahkan oleh penutur asli bahasa yang bersangkutan sekalipun. Hal itu disebabkan kemampuan menulis menghendaki penguasaan berbagai unsur kebahasaan dan unsur luar bahasa itu sendiri yang akan menjadi isi karangan. Baik unsur bahasa maupun unsur isi haruslah terjalin sedemikian rupa sehingga menghasilkan karangan yang runtut dan padu (Nurgiyantoro, 2010:296).

Salah satu pendekatan yang dapat digunakan dalam pembelajaran menulis adalah pendekatan kontekstual. Pendekatan ini dapat dilakukan dengan mengajak peserta didik langsung berinteraksi dengan objek tulisan. Strategi yang dapat digunakan dalam pembelajaran menulis yang kontekstual adalah strategi pembelajaran neighborhood walk. Dryden dan Jeanette Vos (2003:23) mengemukakan bahwa belajar akan lebih menyenangkan jika dilakukan dalam suasana yang menyenangkan.

Berdasarkan uraian di atas, maka tulisan ini difokuskan pada penggunaan strategi pembelajaran neighborhood walk sebagai upaya peningkatan kemampuan menulis siswa di SMK Negeri 1 Polewali. Berdasarkan latar belakang, maka rumusan masalah dalam penelitian ini adalah bagaimanakah peningkatan kemampuan peserta didik kelas XI Perkantoran-1 SMK Negeri 1 Polewali dalam menulis melalui strategi pembelajaran neighborhood walk?

\section{KAJIAN TEORI}

\section{A. Pengertian Menulis}

Lado (dalam Tarigan, 2008:21) mengemukakan bahwa menulis ialah menurunkan atau melukiskan lambang-lambang grafik yang menggambarkan suatu bahasa yang dipahami oleh seseorang, sehingga orang lain dapat membaca lambang-lambang grafik tersebut kalau mereka memahami bahasa dan lambang grafik tersebut. Menulis merupakan suatu representasi bagian dari kesatuan-kesatuan ekspresi bahasa.

Selain itu, Heaten (1975:127) mengungkapkan bahwa menulis adalah kegiatan menyusun kata-kata menjadi kalimat secara benar sesuai dengan kaidah tata bahasa kemudian menghubunghubungkan kalimat tersebut sehingga terbentuk suatu tulisan yang saling berhubungan yang dapat mengomunikasikan pikiran dan ide penulis tentang suatu topik tertentu.

Senada dengan pendapat tersebut, Byrne (1988) mengatakan bahwa menulis dalam arti komunikasi ialah menyampaikan pengetahuan atau informasi tentang subjek. Menulis berarti mendukung ide. Menulis tidak hanya membuat satu kalimat atau hanya beberapa hal yang tidak berhubungan, tetapi menghasilkan serangkaian hal yang teratur, yang berhubungan satu dengan yang lain, dan dalam gaya tertentu. Rangkaian kalimat itu bisa pendek, mungkin hanya dua atau tiga kalimat, tetapi kalimat itu diletakkan secara teratur dan berhubungan satu dengan yang lain, dan berbentuk kesatuan yang masuk akal.

Berdasarkan beberapa konsep menulis di atas dapat dikatakan bahwa menulis merupakan komunikasi tidakl angsung yang berupa pemindahan pikiran dan perasaan dengan memanfaatkan 
grafolog, struktur bahasa, dan kosakata dengan menggunakan simbol-simbol sehingga dapat dibaca seperti apa yang diwakili oleh simbol tersebut.

\section{B. Fungsi dan Tujuan Menulis}

Fungsi utama dari tulisan adalah sebagai alat komunikasi yang tidak langsung. Menulis sangat penting bagi pendidikan karena memudahkan pada pelajar berpikir. Juga dapat menolong kita berpikir secara kritis. Juga dapat memudahkan kita merasakan dan memperdalam daya tanggap atau persepsi kita, memecahkan masalah-masalah yang kita hadapi, menyusun urutan bagi pengalaman. Tulisan dapat membantu kita menjelaskan pikiran-pikiran kita. Setiap penulis memproyeksikan sesuatu mengenai dirinya ke dalam sepenggal tulisan yang objektif (Tarigan, 2008:2).

\section{Ciri-ciri Tulisan yang Baik}

Menurut Ambo Enre (2008, 5-7), tulisan yang baik adalah tulisan yang memiliki ciri-ciri sebagai berikut:

1. Tulisan yang baik selalu bermakna

2. Tulisan yang baik selalu jelas

3. Tulisan yang baik selalu padu dan utuh

4. Tulisan yang baik selalu ekonomis

5. Tulisan yang baik selalu mengikuti kaidah gramatika

Selanjutnya, Cordello (dalam Gie, 2002) mengemukakan bahwa ada tiga hal penting yang perlu diperhatikan dalam menulis, yaitu: (1) menulis adalah melakukan peninjauan, (2) menulis berarti melakukan pemeriksaan, dan (3) menulis berarti membuat naskah. Penulis yang berhasil akan mengetahui bahwa revisi bukan hanya membetulkan kesalahan atau membersihkan naskah, tetapi menambahkan, menghapus, dan mengatur kembali materi teks dengan membuat maksud materi itu jelas bagi pembaca.

Menurut Gie (202), menulis sebagai kegiatan mengungkapkan gagasan melalui bahasa tulis meliputi empat unsur sebagai berikut.

1. Gagasan, dapat berupa pendapat, pengalaman yang ada dalam pikiran seseorang.

2. Tuturan, bentuk pengungkapan gagasan sehingga dapat dipahami pembaca. Dalam kepustakaan teknik mengarang telah lazim dibedakan empat bentuk yaitu penceritaan, pelukisan, pemaparan, dan perbincangan.

3. Tatanan adalah tata tertib pengaturan dan penyusunan gagasan dengan mengindahkan berbagai asas, aturan atau teknik sampai merencanakan rangka dan langkah.

4. Wahana merupakan sarana penghantar gagasan berupa bahasa tulis yang terutama menyangkut kosakata, gramatika, dan retorika (seni memakai bahasa secara efektif). baik.

Keempat unsur menulis tersebut saling kait bersama-sama mewujudkan suatu tuliasan yang

\section{Jenis-jenis Tulisan}

Menurut Ambo Enre (2008:137-194), bentuk tulisan atau karangan dibagi menjadi empat.

1. Eksposisi (pemaparan) 
Eksposisi adalah bentuk tulisan yang menjelaskan suatu objek. Bentuk ini biasa dipakai jika seseorang ingin menjelaskan hakikat sesuatu; bagaimana ia bekerja, bagaimana unsur-unsurnya saling berhubungan satu dengan yang lainnya, dan bagaimana hubungannya dengan sesuatu yang lain. Jika suatu karya tulis berhasil memberikan gambaran yang jelas tentang sesuatu hal atau bagaimana cara kerjanya, maka tujuan pemaparan telah tercapai. Tulisan seperti ini menggugah pikiran tanpa bermaksud menggugah perasaan atau mempengaruhi perasaan atau mempengaruhi sikap pembaca.

\section{Deskipsi (pemerian)}

Pemerian berfungsi menjadikan pembaca seakan-akan melihat wujud sesungguhnya dari materi yang disajikan, sehingga kualitas yang khas dapat dikenal lebih jelas. Dalam jenis tulisan ini yang diutamakan adalah bentuk lahir suatu objek, dengan jalan memberikan atau mengutarakan renikrenik fisiknya yang khusus. Melalui tulisan deskripsi kita melihat suatu objek lebih hidup, konkret, dan utuh.

\section{Narasi (pengisahan)}

Narasi berhubungan dengan penyajian beberapa peristiwa dalam suatu karangan yang utuh. Pokok masalahnya ialah tindakan atau perbuatan dalam hubungannnya dengan suatu peristiwa yang disusun dalam bentuk cerita. Kata cerita sering dihubungkan dengan semua bentuk tulisan yang menunjukkan urutan perkembangan, tetapi pengisahan dalam arti sebenarnya terbatas pada peristiwa dalam kerangka waktu tertentu.

\section{Argumentasi (pendalihan)}

Argumentasi berbeda dengan ketiga bentuk tulisan yang lain karena fungsinya yang bersifat pembuktian. Argumentasi merupakan tulisan yang berisi pendapat yang disertai pembahasan logis dan diperkuat dengan fakta-fakta sehingga pendapat itu diterima kebenarannya.

\section{E. Tujuan dan Ruang Lingkup Pembelajaran Menulis di SMK}

Mata pelajaran Bahasa Indonesia bertujuan agar peserta didik memiliki kemampuan sebagai berikut.

1. Berkomunikasi secara efektif dan efisien sesuai dengan etika yang berlaku, baik secara lisan maupun tulis

2. Menghargai dan bangga menggunakan bahasa Indonesia sebagai bahasa persatuan dan bahasa negara

3. Memahami bahasa Indonesia dan menggunakannya dengan tepat dan kreatif untuk berbagai tujuan

4. Menggunakan bahasa Indonesia untuk meningkatkan kemampuan intelektual, serta kematangan emosional dan sosial

5. Menikmati dan memanfaatkan karya sastra untuk memperluas wawasan, memperhalus budi pekerti, serta meningkatkan pengetahuan dan kemampuan berbahasa

6. Menghargai dan membanggakan sastra Indonesia sebagai khazanah budaya dan intelektual manusia Indonesia.

Berdasarkan uraian di atas, dapat dilihat bahwa salah satu kompetensi dasar menulis yang diajarkan di SMK adalah menulis. Teks eksplanasi merupakan bentuk karangan yang 
menggambarkan suatu objek. Penggambaran suatu objek dilakukan melalui proses pengamatan yang tajam serta penuh perhatian. Hal itu dilakukan sebagai upaya untuk menimbulkan kesan pada objek yang digambarkan. Penggambaran juga dilakukan dengan menambahkan detail-detail yang spesifik.

\section{F. Strategi Neighborhood Walk}

Neighborhood walk merupakan strategi pembelajaran yang berupaya mengenalkan dan memanfaatkan lingkungan sekitar sebagai media dan sumber pembelajaran. Strategi neighborhood walk menuntut aktivitas belajar peserta didik secara aktif. Peserta didik dalam kegiatan belajar akan dibawa ke luar kelas (lingkungan) dan menjadikan lingkungan tersebut sebagai sumber, tempat, dan media belajar (Prasetyo, 2004). Neighborhood walk sebagai suatu strategi pembelajaran dilandasi oleh teori konstruktivisme. Teori ini memandang bahwa anak belajar melalui interaksi dengan orang lain dan benda-benda atau objek yang ada di sekitarnya. Ketika anak berinteraksi, mereka membentuk pemahaman tentang bagaimana dunia atau lingkungan dan orang itu berinteraksi.

Sagala (2003:88) mengemukakan bahwa konstruktivisme merupakan landasan perpikir pendekatan kontekstual, yaitu pengetahuan dibangun sedikit demi sedikit, yang hasilnya diperluas melalui konteks yang terbatas (sempit) dan tidak dengan tiba-tiba. Esensinya adalah bahwa peserta didik harus menemukan dan mentransformasikan suatu informasi kompleks ke situasi lain dan apabila dikehendaki informasi itu menjadi milik mereka sendiri. Dengan dasar ini pembelajaran harus menjadi proses mengonstruksi bukan menerima pengetahuan. Dalam pandangan konstruktivisme, strategi memperoleh lebih diutamakan dibandingkan seberapa banyak peserta didik memperoleh dan mengingat pengetahuan. Untuk itu, tugas guru adalah memfasilitasi proses tersebut dengan: (1) menjadikan pengetahuan bermakna dan relevan bagi peserta didik; (2) memberikan kesempatan peserta didik menemukan dan menerapkan idenya sendiri; dan (3) menyadarkan peserta didik agar menerapkan strategi mereka sendiri dalam belajar.

Sebagai suatu strategi pembelajaran, neighborhood walk merupakan strategi pembelajaran yang didasari pembelajaran yang berpendekatan kontekstual. Belajar menulis dengan memanfaatkan lingkungan merupkan cara belajar yang nyata, yang merupakan salah satu ciri pembelajaran dengan pendekatan kontekstual. Pembelajaran kontekstual adalah konsep pembelajaran yang membantu guru mengaitkan antara materi yang diajarkan dengan situasi nyata peserta didik dan mendorong peserta didik membuat hubungan antara pengetahuan yang dimilikinya dengan penerapannya dalam kehidupan mereka sehari-hari.

Hal ini menurut Nurhadi dan Agus Gerrad Senduk (2003:31) dilakukan dengan melibatkan komponen utama pembelajaran kontekstual yang efektif meliputi konstruktivisne (contructivism), bertanya (questioning), menemukan (inquiry), masyarakat belajar (learning community), pemodelan (modeling), dan penilaian sebenarnya (authentic assessment). Pembelajaran kontekstual tersebut dapat muncul dalam pembelajaran menulis dengan strategi neighborhood walk.

Pelaksanaan pembelajaran menulis dengan penggunaan strategi neighborhood walk memerlukan panduan pelaksanaan pembelajaran. Panduan tersebut terbagi menjadi tiga bagian, yaitu (1) tahap penyusunan rencana pembelajaran, (2) tahap pelaksanaan pembelajaran, dan (3) tahap pengevaluasian pembelajaran. Dalam pelaksanaan pembelajaran menulis laporan dengan strategi neihghborhood walk dipadukan dengan pendekatan proses dalam menulis. Pendekatan proses dalam 
menulis adalah kegiatan menulis yang meliputi beberapa tahap kegiatan. De Porter dan Mike Hernacki (2007:195) mengemukakan tahap kegiatan menulis yaitu persiapan, draft-kasar, berbagi, perbaikan, penyuntingan, dan penulisan kembali. Pada tahap persiapan, kegiatan pembelajaran yang dilakukan peserta didik adalah menentukan objek pengamatan melalui curah pendapat.

Setelah itu, guru mengajak peserta didik untuk berjalan-jalan ke luar ruangan (lingkungan sekitar sekolah) untuk melihat secara langsung objek yang akan menjadi sumber tulisan. Kemudian guru meminta peserta didik secara berkelompok untuk mengidentifkasi dan mengelompokkan objek yang diamati pada format yang telah disediakan, sekaligus peserta didik menulis cepat dan membuat pemetaan secara detail hasil pengamatannya. Dalam kelompoknya, peserta didik mendiskusikan hasil pengamatan yang dilakukan dengan melaporkannya secara lisan. Kegiatan persiapan diakhiri dengan pembuatan kerangka laporan berdasarkan pemetaan yang dibuatnya.

Tahap draft-kasar, kegiatan pembelajaran pada tahap ini adalah peserta didik mulai menulis secara spontan dengan cara mengembangkan kerangka laporan. Penulisan juga dengan memperhatikan aspek koherensi dan aspek kohesif paragraf.

Tahap berbagi, kegiatan ini dilakukan peserta didik dengan membaca draft yang telah dibuatnya, sedangkan temannya yang lain memberikan umpan balik.

Tahap perbaikan, kegiatan yang dilakukan peserta didik adalah menemukan kesalahan yang ada pada tulisan peserta didik lain dalam kelompoknya. Pencarian dan pengoreksian kesalahan ditekankan pada pilihan kata, kalimat, penanda kohesi. Kegiatan penilaian dilakukan melalui penilaian teman sejawat dan kooperatif.

Tahap penyuntingan, difokuskan pada upaya menemukan kesalahan penggunaan tanda baca, penggunaan ejaan, penulisan huruf kapital, awalan, serta pemenggalan kata. Kegiatan penyuntingan dilakukan antarkelompok. Kemudian secara individu, peserta didik menuliskan kembali tulisan yang telah melalui proses penyuntingan.

Tahap penulisan kembali, pada kegiatan ini peserta didik diberi kesempatan untuk menuliskan kembali karangka dengan memasukkan isi yang baru dan perubahan hasil penyuntingan yang telah dilakukan oleh temannya.

Tahap terakhir adalah evaluasi, berisi kegiatan memeriksa kembali apakah pekerjaan peserta didik sudah selesai. Setelah itu, peserta didik memublikasikan laporan yang dibuatnya di depan kelas. Pemublikasian tulisan dilakukan dengan cara membacakannya di depan kelas dengan intonasi yang tepat dan jelas.

Evaluasi yang digunakan dalam pembelajaran menulis dengan strategi neighborhood walk menggunakan evaluasi proses dan hasil. Evaluasi proses dilakukan dalam proses pembelajaran dengan menggunakan lembar observasi dan portofolio. Sedangkan penilaian hasil dilakukan dengan cara menilai aspek-aspek pembentuk teks eksplanasi. Untuk memudahkan pelaksanaan evaluasi hasil, digunakan pedoman penilaian hasil tulisan berupa teks eksplanasi peserta didik.

\section{METODE PENELITIAN}

Penelitian tindakan kelas ini dilaksanakan di SMK Negeri 1 Polewali Semester Ganjil Tahun Pelajaran 2018/2019 pada bulan Agustus sampai Oktober 2018. Subjek penelitian ini adalah peserta didik kelas XI Perkantoran-1 SMK Negeri 1 Polewali Semester Ganjil Tahun Pelajaran 2018/2019 sebanyak 31 peserta didik, 12 laki-laki dan 19 perempuan. 
Instrumen utama dalam penelitian ini adalah peneliti sendiri. Instrumen penunjang adalah pedoman observasi dan portofolio. Pedoman observasi digunakan untuk mengamati latar dan suasana berlangusngnya proses pembelajaran. Pegamatan dilakukan terhadap semua aktivitas yang dilakukan oleh peserta didik dalam pembelajaran menulis teks eksplanasi dengan strategi neighborhood walk. Portofolio yang dimaksud dalam penelitian ini adalah kumpulan semua hasil kegiatan menulis yang telah dilakukan oleh peserta didik. Data dalam penelitian ini dikumpulkan melalui kegiatan observasi dan portofolio peserta didik. Observasi dilakukan untuk mengamati latar dan suasana berlangsungnya tindakan pembelajaran menulis melalui strategi neighborhood walk. Aspek-aspek yang diamati berupa butir-butir sasaran observasi diberikan tanda cek sesuai dengan kenyataan yang ada dan pencatatan deskripsi pembelajaran serta refleksi penelitian tentang pelaksanaan tindakan pembelajaran.

Teknik analisis data dalam penelitian ini menggunakan teknik analisis data yang dikemukakan oleh Moleong (2005:245). Tahap-tahap analisis data tersebut adalah:

1. Menelaah seluruh data

Data yang berhasil dikumpulkan melalui observasi dan portofolio peserta didik ditelaah untuk menyeleksi, memilih, dan mengelompokkan data.

2. Mereduksi data

Tahap ini merupakan kegiatan untuk mengelompokkan dan mengklasifikasi data. Data yang telah terkumpul selama penelitian diseleksi dan diidentifikasi untuk kemudian dikelompokkan sesuai dengan permasalahannya.

3. Rambu-rambu analisis

Analisis data dilakukan berdasarkan rambu-rambu analisis proses dan hasil pembelajaran menulis laporan dalam bentuk teks eksplanasi melalui strategi neighborhood walk. Setelah dilakukan analisis data proses, selanjutnya dilakukan analisis karangan peserta didik setelah tindakan berlangsung pada akhir setiap siklus. Analisis data ini bertujuan menentukan kualifikasi tingkat keberhasilan pelaksanaan tindakan pada tiap siklus. Indikator keberhasilan pembelajar didasarkan pada kriteria ketuntasan minimal (KKM) pada standar kompetensi menulis yaitu 75 .

\section{HASIL PENELITIAN DAN PEMBAHASAN}

\section{A. Hasil Penelitian}

\section{Deskripsi Proses Siklus Pertama}

a. Perencanaan

Perencanaan dalam penelitian ini meliputi: (1) menyusun rencana pelaksanaan pembelajaran, (2) menyusun pedoman pelaksanaan tindakan pembelajaran menulis dengan strategi Neighborhood walk, (3) menyusun format penilaian menulis teks eksplanasi, dan (4) menyusun pedoman observasi.

b. Implementasi tindakan

Aktivitas pembelajaran menulis dalam bentuk teks eksplanasi pada siklus pertama dilaksanakan selama dua kali pertemuan (6 x 45 menit). Pertemuan pertama dengan kegiatan utama 
pramenulis dengan fokus pembelajaran memulai kegiatan pembelajaran, membangkitkan skemata peserta didik, membagi peserta didik dalam kelompok-kelompok kecil terdiri atas 3 - 4 orang tiap kelompok, menentukan objek (lingkungan pengamatan), menentukan tema, topik, dan judul berdasarkan objek, dan membuat kerangka laporan. Setelah tahap pramenulis selesai, selanjutnya peserta didik dan guru mengadakan perjalanan mengelilingi lingkungan sekolah dengan membuat catatan-catatan kecil setiap hal yang dianggap menarik. Setelah kegiatan mengelilingi lingkungan sekolah selesai, peserta didik kembali masuk ke kelas dengan tetap bersama anggota kelompoknya. Tahap selanjutnya adalah pengedrafan. Pada tahap ini peserta didik mengembangkan kerangka tulisan menjadi sebuah bentuk teks eksplanasi berdasarkan tema, topik, dan judul yang telah ditentukan dari hasil pengamatan terhadap objek yang telah diamati.

Pertemuan kedua diisi dengan kegiatan melakukan perbaikan terhadap laporan yang telah ditulis. Tahap perbaikan tulisan dilakukan oleh peserta didik dalam kelompok kecilnya. Setiap anggota kelompok saling memperbaiki tulisan. Setelah itu, setiap karangan dikembalikan kepada pemiliknya masing-masing untuk ditulis ulang sesuai dengan perbaikan yang telah dilakukan oleh temannya. Tahap selanjutnya adalah penyuntingan. Yang dilakukan oleh peserta didik pada tahap ini adalah mencari dan memperbaiki kesalahan pengunaan ejaan dan tanda baca pada tulisan temannya dari kelompok yang berbeda. Tahap terakhir adalah pemublikasian. Tahap pemublikasian dilakukan dengan cara meminta beberapa orang peserta didik untuk membacakan tulisannya di depan kelas.

c. Observasi

Selama proses pembelajaran dilaksanakan, guru mengadakan pengamatan terhadap aktivitas peserta didik. Aktivitas peserta didik yang diobservasi adalah menyimak tujuan pembelajaran; menyimak penjelasan guru mengenai kegiatan yang akan dilakukan; pembentukan kelompok; curah pendapat tentang lingkungan yang akan dijadikan objek pengamatan; mempersiapkan format catatan pengamatan; melakukan pengamatan terhadap objek yang telah ditentukannya; mengidentifikasi objek pengamatan; membuat pemetaan hasil pengamatan objek; mendiskusikan hasil pengamatan objek pada kelompoknya masing-masing; melaporkan secara ringkas hasil pengamatan didapat; membuat laporan berdasarkan tema, topik, dan judul yang telah ditentukan dari hasil pengamatan terhadap objek; keakifan mencari dan memperbaiki kesalahan tulisan temannya dalam satu kelompok, terutama dalam penggunaan pilihan kata, kalimat, dan penanda deskripsinya; memperbaiki tulisan yang dikoreksi oleh rekannya; menyunting tulisan peserta didik lain pada kelompok yang berbeda; dan memperbaiki tulisannya dengan cara menuliskan kembali tulisan yang telah melalui proses penyuntingan.

d. Hasil penilaian terhadap karangan peserta didik pada siklus pertama

Persentase hasil yang dicapai peserta didik pada siklus pertama dapat dilihat pada tabel berikut.

Tabel 1. Hasil yang Dicapai Peserta Didik pada Siklus Pertama

\begin{tabular}{|c|c|c|}
\hline Jumlah Peserta Didik & Persentase & Keterangan \\
\hline 19 & 61,29 & Tuntas \\
\hline 12 & 38,71 & Tidak tuntas \\
\hline
\end{tabular}


Berdasarkan Tabel 1 di atas, digambarkan bahwa pada siklus pertama hanya 19 peserta didik $(61,29 \%)$ yang tuntas, sedangkan 12 peserta didik (38,71\%) belum mencapai nilai KKM (75).

e. Refleksi

Pelaksanaan tindakan pembelajaran siklus pertama pada tahap pramenulis, telah berlangsung baik. akan tetapi pada tahap pengedrafan, perbaikan, penyuntingan, dan pemublikasian belum berlangsung dengan baik. Oleh karena itu, pemberian tindakan perlu dilanjutkan pada siklus kedua.

\section{Deskripsi Proses Siklus Kedua}

a. Perencanaan

Siklus kedua merupakan lanjutan dari siklus pertama berdasarkan hasil refleksi. Perencanaan dalam penelitian ini meliputi: (1) menyusun rencana pelaksanaan pembelajaran dan (2) menyusun pedoman pelaksanaan tindakan pembelajaran menulis karangan narasi dengan strategi Neighborhood walk.

\section{b. Implementasi tindakan}

Aktivitas pembelajaran menulis teks eksplanasi pada siklus kedua juga dilaksanakan selama dua kali pertemuan (6 x 45 menit). Pertemuan pertama dengan kegiatan pramenulis dengan fokus pembelajaran memulai kegiatan pembelajaran, membangkitkan skemata peserta didik, membagi peserta didik dalam kelompok-kelompok kecil terdiri atas 3 - 4 orang tiap kelompok, menentukan objek (lingkungan pengamatan), menentukan tema, topik, dan judul berdasarkan objek, dan membuat kerangka tulisan.

Setelah tahap pramenulis selesai, selanjutnya peserta didik dan guru mengadakan perjalanan mengelilingi lingkungan sekolah dengan membuat catatan-catatan kecil setiap hal yang dianggap menarik. Setelah kegiatan mengelilingi lingkungan sekolah selesai, peserta didik kembali masuk ke kelas dengan tetap bersama anggota kelompoknya. Tahap selanjutnya adalah pengedrafan. Pada tahap ini peserta didik mengembangkan kerangka laporan menjadi sebuah karangan narasi berdasarkan tema, topik, dan judul yang telah ditentukan dari hasil pengamatan terhadap objek yang telah diamati.

Pertemuan kedua diisi dengan kegiatan melakukan perbaikan terhadap karangan yang telah ditulis. Tahap perbaikan tulisan dilakukan oleh peserta didik dalam kelompok kecilnya. Setiap anggota kelompok saling memperbaiki tulisan. Setelah itu, setiap karangan dikembalikan kepada pemiliknya masing-masing untuk ditulis ulang sesuai dengan perbaikan yang telah dilakukan oleh temannya. Tahap selanjutnya adalah penyuntingan. Yang dilakukan oleh peserta didik pada tahap ini adalah mencari dan memperbaiki kesalahan pengunaan ejaan dan tanda baca pada tulisan temannya dari kelompok yang berbeda. Tahap terakhir adalah pemublikasian. Tahap pemublikasian dilakukan dengan cara meminta beberapa orang peserta didik untuk membacakan tulisannya di depan kelas.

\section{c. Observasi}

Selama proses pembelajaran dilaksanakan, guru mengadakan pengamatan terhadap aktivitas peserta didik. Aktivitas peserta didik yang diobservasi adalah menyimak tujuan pembelajaran; menyimak penjelasan guru mengenai kegiatan yang akan dilakukan; pembentukan kelompok; curah pendapat tentang lingkungan yang akan dijadikan objek pengamatan; mempersiapkan format catatan pengamatan; melakukan pengamatan terhadap objek yang telah ditentukannya; mengidentifikasi 
objek pengamatan; membuat pemetaan hasil pengamatan objek; mendiskusikan hasil pengamatan objek pada kelompoknya masing-masing; melaporkan secara ringkas hasil pengamatan didapat; membuat laporan berdasarkan tema, topik, dan judul yang telah ditentukan dari hasil pengamatan terhadap objek; keakifan mencari dan memperbaiki kesalahan tulisan temannya dalam satu kelompok, terutama dalam penggunaan pilihan kata, kalimat, dan penanda deskripsinya; memperbaiki tulisan yang dikoreksi oleh rekannya; menyunting tulisan peserta didik lain pada kelompok yang berbeda; dan memperbaiki tulisannya dengan cara menuliskan kembali tulisan yang telah melalui proses penyuntingan.

d. Hasil penilaian terhadap karangan peserta didik pada siklus kedua

Persentase hasil yang dicapai peserta didik pada siklus kedua dapat dilihat pada Tabel 2 berikut.

Tabel 2. Hasil yang Dicapai Peserta Didik pada Siklus Kedua

\begin{tabular}{|c|c|c|}
\hline Jumlah Peserta Didik & Persentase & Keterangan \\
\hline 27 & 87,10 & Tuntas \\
\hline 4 & 12,90 & Tidak tuntas \\
\hline 31 & 100 & \\
\hline
\end{tabular}

Tabel 2 di atas menunjukkan bahwa terjadi peningkatan yang signifikan terhadap kemampuan menulis peserta didik kelas XI Perkantoran-1 SMK Negeri 1 Polewali. Hal tersebut dapat dilihat dari penambahan jumlah peserta didik yang mencapai nilai KKM.

e. Refleksi

Pelaksanaan tindakan pembelajaran siklus kedua pada tahap pramenulis, tahap pengedrafan, tahap perbaikan, tahap penyuntingan, dan tahap pemublikasian telah berlangsung dengan baik. Namun, masih ada 4 orang atau 12,90\% peserta didik yang belum mencapai KKM. Oleh karena itu, pemberian tindakan masih perlu dilanjutkan pada siklus ketiga.

\section{Deskripsi Proses Siklus Ketiga}

a. Perencanaan

Siklus ketiga merupakan lanjutan dari siklus kedua berdasarkan hasil refleksi. Perencanaan dalam penelitian ini meliputi: (1) menyusun rencana pelaksanaan pembelajaran dan (2) menyusun pedoman pelaksanaan tindakan pembelajaran menulis karangan ekspositif dengan strategi Neighborhood walk.

\section{b. Implementasi tindakan}

Aktivitas pembelajaran menulis laporan dalam bentuk karangan eksplanasi pada siklus ketiga juga dilaksanakan selama dua kali pertemuan (6 x 45 menit). Pertemuan pertama dengan kegiatan pramenulis dengan fokus pembelajaran memulai kegiatan pembelajaran, membangkitkan skemata peserta didik, membagi peserta didik dalam kelompok-kelompok kecil terdiri atas 3 - 4 orang tiap kelompok, menentukan objek (lingkungan pengamatan), menentukan tema, topik, dan judul berdasarkan objek, dan membuat kerangka tulisan.

Setelah tahap pramenulis selesai, selanjutnya peserta didik dan guru mengadakan perjalanan mengelilingi lingkungan sekolah dengan membuat catatan-catatan kecil setiap hal yang dianggap 
menarik. Setelah kegiatan mengelilingi lingkungan sekolah selesai, peserta didik kembali masuk ke kelas dengan tetap bersama anggota kelompoknya. Tahap selanjutnya adalah pengedrafan. Pada tahap ini peserta didik mengembangkan kerangka laporan menjadi sebuah laporan dalam bentuk teks eksplanasi berdasarkan tema, topik, dan judul yang telah ditentukan dari hasil pengamatan terhadap objek yang telah diamati.

Pertemuan kedua diisi dengan kegiatan melakukan perbaikan terhadap katya yang telah ditulis. Tahap perbaikan tulisan dilakukan oleh peserta didik dalam kelompok kecilnya. Setiap anggota kelompok saling memperbaiki tulisan. Setelah itu, setiap karangan dikembalikan kepada pemiliknya masing-masing untuk ditulis ulang sesuai dengan perbaikan yang telah dilakukan oleh temannya. Tahap selanjutnya adalah penyuntingan. Yang dilakukan oleh peserta didik pada tahap ini adalah mencari dan memperbaiki kesalahan pengunaan ejaan dan tanda baca pada tulisan temannya dari kelompok yang berbeda. Tahap terakhir adalah pemublikasian. Tahap pemublikasian dilakukan dengan cara meminta beberapa orang peserta didik untuk membacakan tulisannya di depan kelas.

\section{c. Observasi}

Selama proses pembelajaran dilaksanakan, guru mengadakan pengamatan terhadap aktivitas peserta didik. Aktivitas peserta didik yang diobservasi adalah menyimak tujuan pembelajaran; menyimak penjelasan guru mengenai kegiatan yang akan dilakukan; pembentukan kelompok; curah pendapat tentang lingkungan yang akan dijadikan objek pengamatan; mempersiapkan format catatan pengamatan; melakukan pengamatan terhadap objek yang telah ditentukannya; mengidentifikasi objek pengamatan; membuat pemetaan hasil pengamatan objek; mendiskusikan hasil pengamatan objek pada kelompoknya masing-masing; melaporkan secara ringkas hasil pengamatan didapat; membuat laporan berdasarkan tema, topik, dan judul yang telah ditentukan dari hasil pengamatan terhadap objek; keakifan mencari dan memperbaiki kesalahan tulisan temannya dalam satu kelompok, terutama dalam penggunaan pilihan kata, kalimat, dan penanda deskripsinya; memperbaiki tulisan yang dikoreksi oleh rekannya; menyunting tulisan peserta didik lain pada kelompok yang berbeda; dan memperbaiki tulisannya dengan cara menuliskan kembali tulisan yang telah melalui proses penyuntingan.

d. Hasil penilaian terhadap karangan peserta didik pada siklus ketiga

Persentase hasil yang dicapai peserta didik pada siklus ketiga dapat dilihat pada tabel berikut.

Tabel 3. Hasil yang Dicapai Peserta Didik pada Siklus Ketiga

\begin{tabular}{|c|c|c|}
\hline Jumlah Peserta Didik & Persentase & Keterangan \\
\hline 31 & 100 & Tuntas \\
\hline 0 & 0 & Tidak tuntas \\
\hline
\end{tabular}

Tabel 3 di atas menunjukkan bahwa kemampuan menulis peserta didik kelas XI Perkantoran1 SMK Negeri 1 Polewali sudah sangat baik. Hal tersebut dapat dilihat dari penambahan jumlah peserta didik yang telah mencapai nilai KKM menjadi 100\%.

e. Refleksi 
Pelaksanaan tindakan pembelajaran siklus kedua pada tahap pramenulis, tahap pengedrafan, tahap perbaikan, tahap penyuntingan, dan tahap pemublikasian telah berlangsung dengan sangat baik. Oleh karena itu, pemberian tindakan tidak perlu dilanjutkan pada siklus keempat.

\section{B. Pembahasan}

Permasalahan pokok dalam penelitian ini adalah penerapan strategi pembelajaran neighborhood walk dalam pembelajaran menulis laporan dalam bentuk teks eksplanasi.

Perbandingan persentase hasil yang dicapai peserta didik pada siklus pertama, kedua, dan ketiga dapat dilihat pada tabel berikut.

Tabel 4. Perbandingan Persentase Hasil yang Dicapai Peserta Didik pada Siklus Pertama, Kedua, dan Ketiga.

\begin{tabular}{|c|c|c|c|c|c|c|}
\hline \multicolumn{2}{|c|}{ Siklus Pertama } & \multicolumn{2}{|c|}{ Siklus Kedua } & \multicolumn{2}{|c|}{ Siklus Ketiga } & \multirow[b]{2}{*}{ Ket. } \\
\hline $\begin{array}{c}\text { Jumlah } \\
\text { Peserta } \\
\text { Didik }\end{array}$ & Persentase & $\begin{array}{c}\text { Jumlah } \\
\text { Peserta } \\
\text { Didik }\end{array}$ & Persentase & $\begin{array}{c}\text { Jumlah } \\
\text { Peserta } \\
\text { Didik }\end{array}$ & Persentase & \\
\hline 5 & 16,13 & 22 & 70,97 & 31 & 100 & Tuntas \\
\hline 26 & 83,87 & 9 & 29,03 & 0 & 0 & $\begin{array}{l}\text { Tidak } \\
\text { tuntas }\end{array}$ \\
\hline 31 & 100 & 31 & 100 & 31 & 100 & \\
\hline
\end{tabular}

Hasil penilaian terhadap tulisan peserta didik pada siklus pertama menunjukkan bahwa hanya lima peserta didik atau $16,13 \%$ yang mencapai nilai KKM (75), sedangkan 26 peserta didik atau $83,87 \%$ yang nilainya masih berada di bawah nilai KKM.

Setelah pelaksanaan tindakan pada siklus kedua, hasil penilaian tulisan peserta didik menunjukkan bahwa hanya sembilan peserta didik atau $29,03 \%$ yang nilainya tidak mencapai nilai KKM, sedangkan 22 peserta didik atau 70,97\% yang nilainya mencapai bahkan melampaui nilai KKM. Selanjutnya, pada siklus ketiga, 31 peserta didik atau 100\% telah mencapai bahkan melalpaui nilai KKM. Hasil penelitian tersebut menunjukkan bahwa dengan penerapan strategi pembelajaran neighborhood walk, dapat meningkatkan kemampuan peserta didik menulis. Siklus pertama menunjukkan bahwa hanya lima peserta didik atau 16,13\% yang mencapai nilai KKM (75), sedangkan 26 peserta didik atau 83,87\% yang nilainya masih berada di bawah nilai KKM. Namun, setelah pelaksanaan siklus kedua terjadi peningkatan hasil menulis peserta didik menjadi 22 peserta didik atau $70.97 \%$ yang nilainya mencapai nilai KKM dan hanya 9 peserta didik atau 29,03\% yang nilainya tidak mencapai nilai KKM. Dan pada siklus ketiga, 31 peserta didik atau $100 \%$ telah mencapai bahkan melalpaui nilai KKM.

Berdasarkan hasil yang diperoleh peserta didik pada hasil penelitian dapat diuraikan bahwa ternyata apabila peserta didik mengonstruksi sendiri pengetahuannya, maka mereka akan lebih cepat memahami pengetahuan tersebut. Hal ini sejalan dengan hal yang diungkapkan oleh Sagala (2003:88) esensinya dari pembelajaran konstruktivisme adalah bahwa peserta didik harus menemukan dan mentransformasikan suatu informasi kompleks ke situasi lain dan apabila dikehendaki informasi itu 
menjadi milik mereka sendiri. Dengan dasar ini pembelajaran harus menjadi proses mengonstruksi bukan menerima pengetahuan.

Dalam pandangan konstruktivisme, tersebut, strategi memperoleh lebih diutamakan dibandingkan seberapa banyak peserta didik memperoleh dan mengingat pengetahuansehingga tugas guru adalah memfasilitasi proses tersebut dengan: (1) menjadikan pengetahuan bermakna dan relevan bagi peserta didik; (2) memberikan kesempatan peserta didik menemukan dan menerapkan idenya sendiri; dan (3) menyadarkan peserta didik agar menerapkan strategi mereka sendiri dalam belajar.

Strategi pembelajaran neighborhood walk yang merupakan strategi pembelajaran yang didasari pembelajaran yang berpendekatan kontekstual, ternyata dapat meningkatkan kemampuan menulis peserta didik secara signifikan dengan memanfaatkan lingkungan. Pelaksanaan pembelajaran menulis dengan penggunaan strategi neighborhood walk berjalan sesuai dengan panduan pelaksanaan pembelajaran. Hal yang dilakukan adalah melaksanakan langkah-langkah pemebelajaran menulis sesuai dengan pendapat De Porter dan Mike Hernacki (2007:195) yang menyatakan bahwa tahap kegiatan menulis yaitu persiapan, draft-kasar, berbagi, perbaikan, penyuntingan, dan penulisan kembali. Pada tahap persiapan, kegiatan pembelajaran yang dilakukan peserta didik adalah menentukan objek pengamatan melalui curah pendapat, setelah guru mengajak peserta didik untuk berjalan-jalan ke luar ruangan (lingkungan sekitar sekolah) untuk melihat secara langsung objek yang akan menjadi sumber tulisan.

\section{SIMPULAN DAN SARAN}

\section{A. Simpulan}

Berdasarkan hasil penelitian dan pembahasan disimpulkan bahwa ada peningkatan kemampuan peserta didik kelas XI Perkantoran-1 SMK Negeri 1 Polewali dalam menulis melalui penerapan strategi pembelajaran neighborhood walk. Setelah diadakan proses pembelajaran yang berlangsung selama tiga siklus diperoleh hasil yaitu pada siklus pertama, hasil menulis peserta didik menunjukkan bahwa 19 peserta didik atau 61,29\% yang mencapai nilai KKM (75), sedangkan 12 peserta didik atau 38,71\% yang nilainya berada di bawah nilai KKM. Pada siklus kedua, hasil menulis peserta didik menjadi 27 peserta didik atau 87,10\% yang nilainya mencapai nilai KKM dan hanya empat peserta didik atau 12,90\% yang nilainya tidak mencapai nilai KKM. Pada siklus ketiga, hasil yang dicapai oleh peserta didik adalah tuntas $100 \%$.

\section{B. Saran}

Berdasarkan hasil penelitian dan simpulan yang telah dikemukakan maka disarankan agar guru bahasa dan sastra Indonesia semaksimal mungkin menerapkan strategi pembelajaran neighborhood walk dalam meningkatkan kemampuan menulis peserta didik. Selanjutnya, kepada pihak-pihak yang terkait agar memfasilitasi pengetahuan guru tentang strategi pembelajaran neighborhood walk, khususnya bagi guru bahasa dan sastra Indonesia.

\section{DAFTAR PUSTAKA}


Ambo Enre, Fachruddin. Dasar-dasar Keterampilan Menulis. Ujung Pandang: Badan Penerbit IKIP Ujung Pandang, 2008.

Arikunto, Suharsimi, dkk. Penelitian Tindakan Kelas. Cetakan Kelima. Jakarta: Bumi Aksara, 2008. Byrne, Dom. Teaching Writing Skill. New York: Longman, 1988.

De Porter, Bobbi dan Mike Hernacki. Quantum Learning: Membiasakan Belajar Nyaman dan Meneyenangkan. Bandung: Kaifa, 2007.

Dryden, Gordon dan Jeanette Vos. Revolusi Cara Belajar. Bagian I. Bandung: Kaifa, 2003.

Gie, The Liang. Terampil Mengarang. Yogyakarta: Andi, 2002.

Heaten, J.B. Writing English Language Test. New York: Longman Handbook, 1975.

Moleong, Lexy J. Metodologi Penelitian Kualitatif. Edisi Revisi. Bandung: Remaja Rosdakarya, 2005.

Nurgiyantoro, Burhan. Penilaian dalam Pengajaran Bahasa dan Sastra Indonesia. Yogyakarta: BPFE, 2010.

Nurhadi dan Agus Gerrad Senduk. Pembelajaran Kontekstual dan Penerapannya dalam KBK. Malang: UM Press, 2003.

Prasetyo, Budi. 2004. Peningkatan Pembelajaran Menulis dengan Strategi Neighborhood Walk di Kelas 2 SMP 4 Tanah Grogot. Tesis. Tidak Diterbitkan. Universitas Negeri Malang.

Suherli, dkk. Buku Guru Bahasa Indonesia SMA/MA/SMK/MAK Kelas XI. Jakarta: Kemendikbud, 2017.

Suparno. Pembelajaran Bahasa Indonesia dengan Pendekatan Kontekstual. Makalah Disajikan dalam Simposium Guru di Wisma Raya Bogor, 2 - 6 November 2001.

Sagala, Syaiful. Konsep dan Makna Pembelajaran. Bandung: Alfabeta, 2003.

Tarigan, Henry Guntur. Menulis sebagai Suatu Keterampilan Berbahasa. Bandung: Angkasa, 2008. 